\title{
S12 - Helicobacter pylori HtrA: una proteasa universalmente expresada en cepas aisladas alrededor del mundo con potencial terapéutico
}

\author{
Francisco Rivas-Traverso \\ Programa de Maestría en Ciencias Biológicas, Universidad de Panamá, Panamá
}

*Autor al que se dirige la correspondencia: lparamo2014@gmail.com

\section{Resumen}

\begin{abstract}
T as proteasas y chaperonas HtrA exhiben un papel importante en las respuestas de control de calidad de las

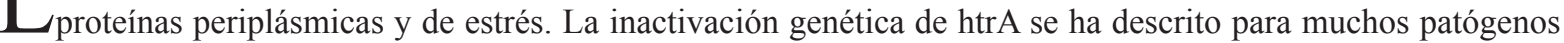
bacterianos, sin embargo, en algunos casos, tales como el patógeno gástrico Helicobacter pylori, HtrA escinde el supresor tumor de tipo E-cadherina interfeririendo con el desarrollo de enfermedad gástrica. Aquí, mostramos que el locus del gen htrA está altamente conservada en las cepas en todo el mundo. La presencia de HtrA se confirmó en 992 aislamientos de H. pylori en biopsias gástricas de pacientes infectados. Se demuestra que H. pylori htrA es un gen esencial bifuncional con funciones cruciales intracelulares y extracelulares. Por lo tanto, como se describe aquí el primer patógeno en el que un gen htrA es indispensable, una situación única en el reino bacteriano. Por lo tanto, HtrA se puede considerar un nuevo objetivo prometedor para la terapia anti-bacteriana.
\end{abstract}

Palabras claves: Enfermedad gástrica, cáncer gástrico

\begin{abstract}
$\mathrm{H}^{\prime}$ trA proteases and chaperones exhibit important roles in periplasmic protein quality control and stress responses. The genetic inactivation of HtrA has been described for many bacterial pathogens, however, in some cases such as the gastric pathogen Helicobacter pylori, HtrA is secreted where it cleaves the tumour suppressor E-cadherin interfering with gastric disease development, but the generation of htrA mutants is still lacking. Here, we show that the HtrA gene locus is highly conserved in worldwide strains. We show that Helicobacter htrA is an essential bifunctional gene with crucial intracellular and extracellular functions. Thus, we describe here the first microbe in which htrA is an indispensable gene, a situation unique in the bacterial kingdom. HtrA can therefore be considered a promising new target for anti-bacterial therapy.
\end{abstract}

Keywords: Gastric disease, gastric cancer 